\title{
Glenn Snow, 1930 to 2003
}

\author{
R. C. Schmidtling and R. A. Schmidt
}

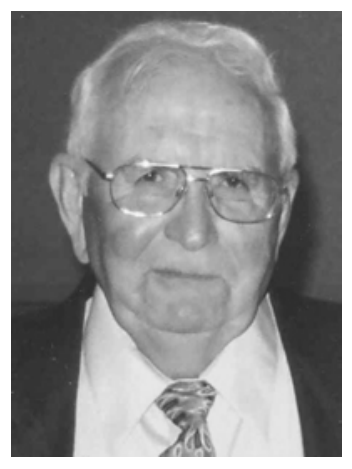

Glenn Austin Snow passed away 5 August 2003 after a long fight with cancer. He is survived by his wife of 49 years, Dolores, his children Alan Mark, Albert Lee, Carroll Wayne, and Barbara Frances, and seven grandchildren.

$\mathrm{He}$ was born in Carrizozo, New Mexico, in 1930. He attended primary and secondary school in Carrizozo, and later received a Bachelor of Science degree in Agricultural Biology from New Mexico State University. He received a Master of Science degree in plant pathology from Colorado State University and a Ph.D. degree in plant pathology from North Carolina State University. He served in Korea as a first lieutenant in the 24th Infantry Division of the United States Army.

His professional career began with the New Mexico State Department of Health working as a District Sanitarian. In 1957, he joined the Southern Forest Experiment Station of the U.S. Forest Service in Gulfport, Mississippi. There he worked as a research plant pathologist and project leader until his retirement in 1990.

Glenn's major research was fusiform rust of slash pine and brown spot needle blight of longleaf pine. His early research on spore dispersal and infection biology of the rust pathogen contributed greatly to a better understanding of the epidemiology of the disease, including important developments in rust hazard evaluation, disease management and aspects of screening for disease resistance. He also contributed important research on control of fusiform rust in forest tree nurseries so that disease-free planting stock would be available. Glenn then turned his attention to characterizing variability in the fusiform rust-slash pine pathosystem where his studies were classical in forest pathology and set the stage for much of the current research on the genetics of disease resistance. Along the way, Glenn developed a quantitative inoculation system which is still a preferred way to challenge specific pine seedlings with sources of the pathogen. He collaborated in a paper describing several form species of Cronartium quercuum which renamed the fusiform rust pathogen C. quercuum f. sp. fusiforme.

During his career, he published over 70 research papers. In 1983, he received the Southern Forest Pathologists Award. In addition to being a long-time member of The American Phytopathological Society, he was active in civic and church affairs. In retirement, he served as a consultant to a task-force seeking to determine the cause of the decline of the live oaks on the Mississippi Gulf Coast. He will long be remembered for his dedication to science, his mentorship, and his dry wit. 